\title{
Soil-transmitted helminth infections in relation to the knowledge and practice of preventive measures among school children in rural communities in South-Eastern Nigeria
}

\author{
Ekaette Edelduok $^{1}$, Joseph Eyo ${ }^{2}$, Emem Ekpe $^{1}$ \\ ${ }^{I}$ Department of Biological Sciences, Akwa Ibom State University, Ikot Akpaden, MkpatEnin, Nigeria \\ ${ }^{2}$ Department of Zoology, University of Nigeria, Nsukka, Enugu State, Nigeria
}

\begin{abstract}
The relationship between soil-transmitted helminth infections and the knowledge and practice of preventive measures among school children in rural communities in Igbo-Eze South Local Government Area of Enugu State, South-Eastern Nigeria, was investigated. Stool samples were obtained from 1,296 school children (ages $4-15$ years) from six schools randomly selected from the study area. Structured epidemiological questionnaires were administered to the children. Out of 1,296 school children examined, 106 (8.1\%) of the children were infected by soil-transmitted infections thus: 64 (4.9\%) with Ascarislumbricoides, 33 (2.5\%) with hookworm, and 9 (0.7\%) with Trichuristrichiura. There were significant differences in the prevalence of these infections $(P<0.05)$. Soil-transmitted helminth infections showed statistically significant $(P<0.05)$ relationships with knowledge and practice of preventive measures among school children in the study area. The study revealed that soil-transmitted helminth infections were abundant among school children of the study area, indicating the necessity of implementing control measures such as chemotherapy, provision of adequate sanitary facilities and safe drinking water.
\end{abstract}

Keywords -Preventive measures, rural communities, school children, soil-transmitted helminths

\section{Introduction}

Soil-transmitted helminth (STH) infections are a major health problem in many developing countries. It is estimated that more than one billion of the world's population, including at least 400 million school-age children are chronically infected with soil-transmitted helminths such as Ascarislumbricoides, Trichuristrichiura, and the hookworms, Ancylostomaduodenale and Necatoramericanus [1]. School-age children infected with soil-transmitted helminths usually have malnutrition, growth stunting, intellectual retardation, and cognitive and educational deficits $[2,3,4,5]$. Clearly, soil-transmitted helminth infections remain an enormous public health problem in the 21 st century.

Measures aimed at controlling soil-transmitted helminth infections are based on regular anthelminthic treatment, improved water supply, sanitation and health education $[6,7,8]$. These control measures can be successfully implemented with information on the prevalence of infections based on baseline surveys. World Health Organization (WHO) recommends a baseline survey in school children to determine the prevalence of infections [9] and to develop effective treatment strategies and case management options [10]. Baseline surveys also provide basis for development of control programmes at national, regional and district levels.

Many studies previously carried out in Nigeria gave due attention to the distribution of different soiltransmitted helminth infections in different explanatory groups such as preschool children, school children and pregnant women $[11,12,13,14,15,16,17,18,19,20]$. However, much still remains to be known about soiltransmitted helminth infections in relation to the knowledge and practice of preventive measures among school children, especially in the study area, Igbo-Eze South. Thus, this study was carried out to investigate the relationship between soil-transmitted helminth infections and the knowledge and practice of preventive measures among school children in the study area. It is hoped that the results of this study will be useful to both researchers and health authorities in the diagnosis, planning and implementation of control programmes for soiltransmitted helminth infections in the area.

\subsection{Study area}

\section{Materials and Methods}

The study was carried out in Igbo-Eze South Local Government Area (LGA) of Enugu State, SouthEastern Nigeria. The various communities in Igbo-Eze South LGA include Ibagwa-Aka, Iheakpu-Awka, Uhonowerre, Iheaka, Ovoko, NkalaguObukpa, Itchi, Alor-Agu and Unadu. The headquarters is at Ibagwa-Aka. There are three development councils in the area; Igbo-Eze South Central, Ekete and Udeze. 
Igbo-Eze South LGA is located between latitudes $7^{0} 19^{l}$ East and $7^{0} 28^{l}$ East, and longitudes $7^{0} 00^{l}$ North and $6^{0} 53^{l}$ North [21]. The area is in the guinea savannah forest mosaic zone of Nigeria. The study area has two main seasons; the rainy and dry seasons. The rainy season usually starts in April and ends in September while the dry season usually starts in October and ends in March. The soil is moist and porous which favours the survival of soil-transmitted helminths ova. The inhabitants of this area are mainly subsistent farmers and traders. There are seventeen health centres in the area, with a GeneralHospital at Itchi. There are forty-four primary schools with 14,994 pupils in the study area; 8,860 males and 6,134 females [22]. Each of the schools have six classes; Primary $1-6$. The total population of people in the study area is 75,368 [23].

\subsection{Selection of schools}

Six schools were used for this study. Primary schools in the study area were listed out and two schools were selected from each developmental council using random sampling technique. The schools selected for this study were Township School 1, Ibagwa, Community Primary School 3, Itchi, Central School, Ovoko, Central School, Iheaka, Community Primary School 1, Unadu and Community Primary School, Iheakpu-Awka. Table of random numbers was used for the random sampling. From each of the six schools selected, thirty-six pupils were selected and sampled using again the random sampling technique. Table of random numbers was again used for the random sampling. Six pupils were selected from each class (classes $1-6$ ) to make up a total of 36 . This was done using the register of each class. When any selected pupil was absent, a pupil after the indicated one was sampled for replacement. A total of 1,296 pupils were sampled at the end of six months.

\subsection{Ethical consideration}

Verbal consent was obtained from headmasters/headmistresses of the schools. In addition, a meeting was held with the parents/guardians of the pupils, informing them of the importance of the study and seeking for their consent. Consent was obtained from the parents. Anyone not willing to take part in the study was excluded. Pupils who were positive for soil-transmitted helminth infections were treated accordingly by appropriate anthelminthic drugs.

\subsection{Collection and examination of stool samples}

Stool samples were collected monthly for a period of six months. Each of the selected pupils was given a small bottle in which they collected their stool samples. The bottles were labeled with the pupil's name, age and sex. On collection of the stool samples, they were taken to the Parasitology laboratory for examination. The stool samples were examined according to the methods of [24]. The number of pupils infected with soiltransmitted helminths, and the type of soil-transmitted helminths observed were recorded.

\subsection{Knowledge and practice of preventive measures}

Well-structured questionnaire based on the known risk factors of soil-transmitted helminth infections was developed. The questionnaire addressed the presence of latrine and its usage, water source for drinking and other domestic uses, and other risk factors. The ages and sexes of the pupils were also included in the questionnaire. Responses of pupils to the questionnaire were correlated with the presence or absence of soiltransmitted helminth infections.

\subsection{Data analysis}

Differences in the prevalence of infection between ages and sexes were determined using the $\chi^{2}$ tests from the contingency tables. The analysis was done using the Epi-info database package (Centre for Disease Control and Prevention, Atlanta, GA) and SPSS (Statistical Package for Social Sciences) version 11.0.

\section{Results}

\subsection{Prevalence of soil-transmitted helminth infections among school children}

Of the 1296 school children examined for soil-transmitted helminth infections, $106(8.1 \%)$ were infected with soil-transmitted helminths thus; 64 (4.9\%) were infected with A. lumbricoides, $33(2.5 \%)$ were infected with hookworm while $9(0.7 \%)$ were infected with T. trichiura. However, within the infected group (106), the prevalence was $60.4 \%, 31.1 \%$ and $8.5 \%$ for A. lumbricoides, hookworm and T. trichiurainfections respectively (TABLE 1$)$. There was significant difference in the prevalence of infections among the school children $(\mathrm{P}<0.05)$. 
Table 1: Prevalence of soil-transmitted helminth infections among school children in the study area

\begin{tabular}{|c|c|c|c|}
\hline $\begin{array}{l}\text { Soil-transmitted } \\
\text { helminths found }\end{array}$ & No. infected & $\begin{array}{l}\text { Overall prevalence } \\
(\%)\end{array}$ & $\begin{array}{l}\text { Prevalence (\%) within the infected } \\
\text { group (106) }\end{array}$ \\
\hline A. lumbricoides & 64 & 4.9 & 60.4 \\
\hline Hookworm & 33 & 2.5 & 31.1 \\
\hline T. trichiura & 9 & 0.7 & 8.5 \\
\hline Total & 106 & 8.1 & 100.0 \\
\hline
\end{tabular}

3.2Relationship between type of latrine system used and the prevalence of soil-transmitted infections

Of the 1296 pupils examined, pupils using open field for defecation had the highest prevalence of infections thus; $19.3 \%$ for A. lumbricoides, $7.2 \%$ for hookworm, and $28.2 \%$ for T. trichiura. There were no infections in pupils using water closet latrine system (TABLE 2). There were significant differences between latrine type used and the prevalence of A. lumbricoidesand hookworm infections $(\mathrm{P}<0.05)$. There was no significant difference between latrine type used and the prevalence of $T$. trichiurainfection $(\mathrm{P}>0.05)$.

Table 2: Relationship between type of latrine system used and the prevalence of soil-transmitted helminth infections in the study area

\begin{tabular}{|c|c|c|c|c|c|c|c|}
\hline \multirow{2}{*}{$\begin{array}{l}\text { Latrine } \\
\text { system }\end{array}$} & \multirow{2}{*}{$\begin{array}{l}\text { No. of } \\
\text { pupils using } \\
\text { it }\end{array}$} & \multicolumn{2}{|c|}{ A. lumbricoides } & \multicolumn{2}{|c|}{ Hookworm } & \multicolumn{2}{|c|}{ T. trichiura } \\
\hline & & $\begin{array}{l}\text { No. } \\
\text { infected }\end{array}$ & $\begin{array}{l}\text { Prevalence } \\
(\%)\end{array}$ & $\begin{array}{l}\text { No. } \\
\text { infected }\end{array}$ & $\begin{array}{l}\text { Prevalence } \\
(\%)\end{array}$ & $\begin{array}{l}\text { No. } \\
\text { infected }\end{array}$ & $\begin{array}{l}\text { Prevalence } \\
(\%)\end{array}$ \\
\hline Open field & $124(9.6 \%)$ & 24 & 19.3 & 9 & 7.2 & 35 & 28.2 \\
\hline Pit latrine & $\begin{array}{l}1150 \\
(88.7 \%)\end{array}$ & 40 & 3.5 & 24 & 2.1 & 71 & 6.2 \\
\hline $\begin{array}{l}\text { Water } \\
\text { closet }\end{array}$ & $22(1.7 \%)$ & 0 & 0 & 0 & 0 & 0 & 0 \\
\hline Total & $\begin{array}{l}1296 \\
(100 \%)\end{array}$ & 64 & 4.9 & 33 & 2.5 & 106 & 8.1 \\
\hline
\end{tabular}

Fig. 1 below shows the relationship between latrine type used and the prevalence of A. lumbricoides, hookworm and T. trichiura infections. From Figure 1, it can be seen that those that used open field for defecation had the highest prevalence of intestinal helminth infections, followed by those that used pit latrine. Those that used water closet system were not infected.
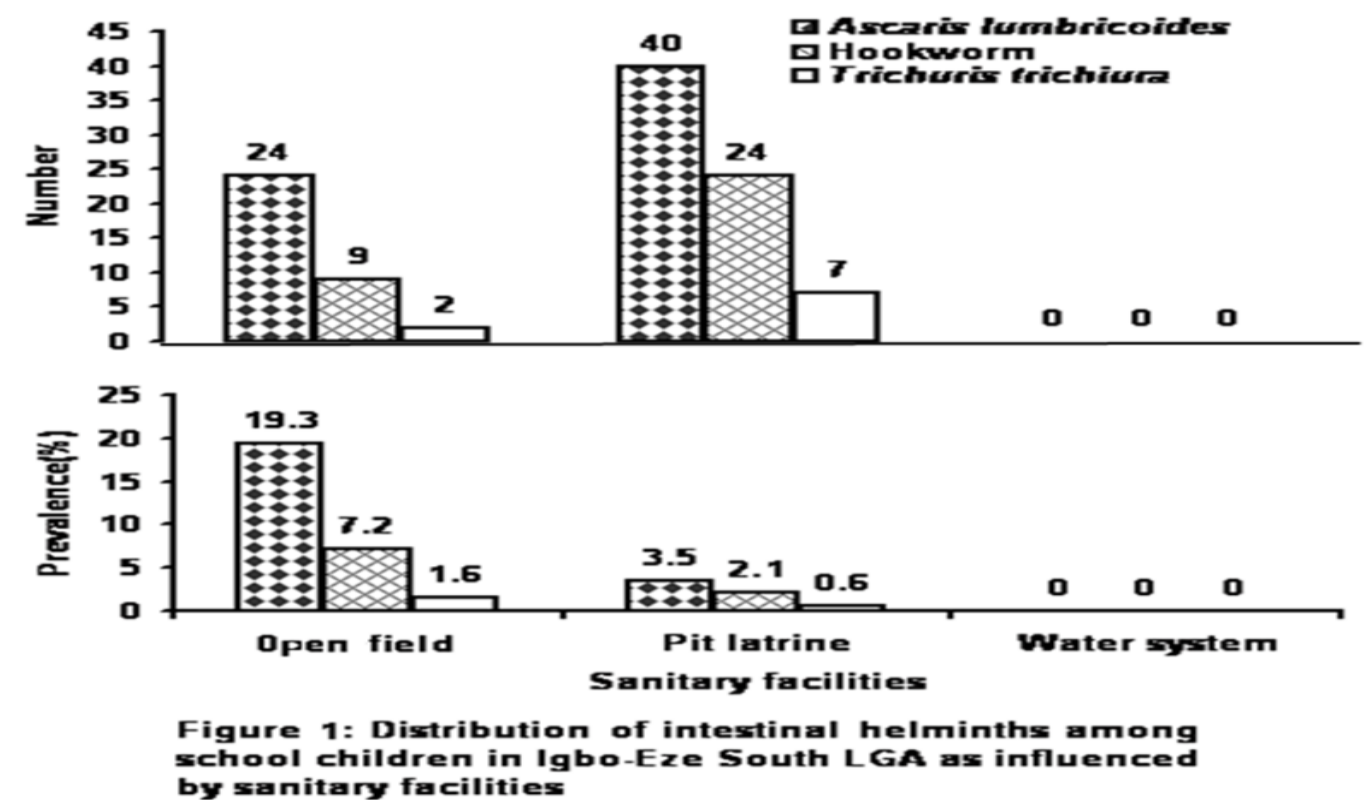

3.3Relationship between source of drinking water and soil-transmitted helminth infections in the study area

Out of the 1296 school children sampled, $654(50.5 \%)$ used water from tankers, $426(32.9 \%)$ used water from wells while 216 (16.7 \%) used water from taps (TABLE 3). School children that used tap water had the least prevalence of A. lumbricoides $(4.9 \%)$ and hookworm $(2.5 \%)$ infections. Those that used water from 
tankers had the highest prevalence for A. lumbricoides $(37.5 \%)$ while those that used water from wells had the highest prevalence of infections for hookworm $(48.5 \%)$ and $T$. trichiura $(44.4 \%)$. There was significantdifference between water source and the prevalence of $A$. lumbricoides infection $(\mathrm{P}<0.05)$. There was no significant difference between water source and the prevalence of hookworm infection $(\mathrm{P}>0.05)$. There was no significant difference between water source and the prevalence of $T$. trichiura infection $(\mathrm{P}>0.05)$.

Table 3: Relationship between source of drinking water and the prevalence of soil-transmitted helminth infections in the study area

\begin{tabular}{|c|c|c|c|c|c|c|c|}
\hline \multirow{2}{*}{$\begin{array}{l}\text { Source } \\
\text { of } \\
\text { drinking } \\
\text { water }\end{array}$} & \multirow{2}{*}{$\begin{array}{l}\text { No. of pupils } \\
\text { using it }\end{array}$} & \multicolumn{2}{|c|}{ A. lumbricoides } & \multicolumn{2}{|c|}{ Hookworm } & \multicolumn{2}{|c|}{ T. trichiura } \\
\hline & & $\begin{array}{l}\text { No. } \\
\text { infected }\end{array}$ & $\begin{array}{l}\text { Prevalence } \\
(\%)\end{array}$ & $\begin{array}{l}\text { No. } \\
\text { infected }\end{array}$ & $\begin{array}{l}\text { Prevalence } \\
(\%)\end{array}$ & $\begin{array}{l}\text { No. } \\
\text { infected }\end{array}$ & $\begin{array}{l}\text { Prevalence } \\
(\%)\end{array}$ \\
\hline Tanker & $654(50.5 \%)$ & 24 & 37.5 & 10 & 30.3 & 2 & 22.2 \\
\hline Well & $426(32.9 \%)$ & 23 & 35.9 & 16 & 48.5 & 4 & 44.4 \\
\hline Tap & $216(16.7 \%)$ & 17 & 26.6 & 7 & 21.2 & 3 & 33.3 \\
\hline
\end{tabular}

\section{Discussion}

This study has shown that soil-transmitted helminth infections are prevalent in the study area. Among the soil-intestinal helminths observed, A. lumbricoides had the highest prevalence (4.9\%), followed by hookworm $(2.5 \%)$, while $T$. trichiura had the least $(0.7 \%)$ (TABLE 1). The higher prevalence of $A$. lumbricoides infection than that of hookworm infection and T. trichiura infection is consistent with some previous reports $[13,15]$.

There were significant differences between the type of latrine system used and the prevalence of $A$. lumbricoides and hookworm infections $(\mathrm{P}<0.05)$. This indicated that there was a direct relationship between the type of latrine system used and the prevalence of these infections. There was no significant difference between the type of latrine system used and the prevalence of $T$. trichiurainfection suggesting that there was no relationship between the type of latrine system used and the prevalence of $T$. trichiurainfection. Those who used water closet latrine system had no infections (0.0 \%) (TABLE 2; Fig. 1). This was in contrast to those using pit latrine and bush, both of which had infections. However, infections were more prevalent in those using bush (Fig. 1). This is not unexpected. According to [25], in a setting in which indiscriminate defecation prevails, it is easy for the general surroundings to become polluted or contaminated with human wastes containing infective agents like eggs of parasitic worms. Also, [26] and [27] noted that the use and availability of latrines enhanced the reduction of helminth infections. It therefore follows that the establishment and maintenance of suitable and efficient excreta disposal facilities will limit the spread of parasitic infections.

The result of this study is consistent with that of [28] where they reported of increased prevalence of intestinal helminths infections due to bad defecation practices. Also, this result suggests that the type of latrine system used has a majorimpact on the prevalence of intestinal helminths infections among school children.

There were significant differences between source of drinking water and the prevalence of $A$. lumbricoides infection $(\mathrm{P}<0.05)$. Moreover, those using water from tankers had the highest prevalence of $A$. lumbricoidesinfections (TABLE 3). This suggests that probably, the water supplied to the people from tankers is not safe. Therefore, relevant authorities should endeavor to check the purity of water being supplied to the communities. The source of drinking water may therefore be said to have a direct effect on the prevalence of $A$. lumbricoides infection. There was no significant difference between source of drinking water and the prevalence of hookworm infections ( $\mathrm{P}>0.05$ ), and no significant difference between source of drinking water and the prevalence of $T$. trichiura infections $(\mathrm{P}>0.05)$. This suggests that source of drinking water does not affect the prevalence of either hookworm infections or $T$. trichiurainfections. This may be so because the route of hookworm infection is usually through skin penetration.

The result of this study revealed that those using tap water had lower prevalence of intestinal helminths infections (TABLE 3). This report is similar to that of [26] in which they indicated that the use and availability of safe water sources enhanced a reduction in the prevalence of intestinal helminths infections. Poor water sources have been known to increase the prevalence of intestinal helminths infections [27]. Moreover, this result revealed that the percentage of those using tap water was the lowest $(16.7 \%)$ compared to those using pumps $(32.9 \%)$ or tanks $(50.5 \%)$ (TABLE 3 ). Thus, the government should make more effort in providing potable drinking water as this would reduce the prevalence of soil-intestinal helminth infections.

\section{Conclusion}

Soil-intestinal helminth infections are prevalent among school children in the study area. Thus, efforts should be made to undertake adequate control measures against soil-transmitted helminth parasites in the area. 
In order to reduce the morbidity associated with soil-transmitted helminth infections, the practice of preventive measures such as using a proper latrine system (water closet) and drinking of potable water (tap water), which the present study has shown to be effective, should be encouraged. In addition, large-scale deworming should be carried out. However, where water supplies and sanitation remain poor, chemotherapy cannot be relied on for sustainable reductions in the prevalence of infections. Therefore, the government should aid in the provision of safe and adequate water supply and construction of latrine to reduce open field defecation. Health education aimed at bringing positive behavioural change in the area should be intensified.

\section{Acknowledgements}

The authors thank the headmasters/headmistresses, teachers and pupils of the schools sampled in this study for their cooperation and understanding throughout the period of this research. Thanks are also due to the parents/guardians for their consent in allowing the pupils to participate in this study.

\section{References}

[1]. WHO, It's a wormy world. World Health Organization (Document WHO/CTD/SIP/98.4), Geneva, 1998

[2]. N. R. De Silva, H. L. Guyatt and D. A. Bundy, Morbidity and mortality due to Ascaris-induced intestinal Transactions of the Royal Society of Tropical Medicine and Hygiene, 91, 1997, 31 - 36.

[3]. L. S. Stephenson, M. C. Latham, S. N. Kinoti, K. M. Kurz and H. Brigham, Improvement in physical fitness of Kenya schoolboys infected with hookworm, Trichuristrichiuraand Ascarislumbricoides following a single dose of Albendezole,Transactions of the Royal Society of Tropical Medicine and Hygiene, 84, 1998, 277 - 282.

[4]. WHO, Deworming for health and development. Report of the third global meeting of the partners for parasitic control. Geneva, 2005.

[5]. J. Bethony, S. Brooker, M. Albonico, S. M. Geiger, A. Loukas, D. Diemert and P. J. Hotez, Soil- transmited helminth infections: Ascariasis, trichuriasis, and hookworm. Lancet, 367, 2006, 1521 - 1532.

[6]. D. W. T. Crompton, How much human helminthiasis is there in the world? Journal of Parasitology, 85, 1999,397 - 403.

[7]. World Bank, School deworming at a glance.Public health at a glance series (http://www.worldbank.org/hnp), 2003.

[8]. M. Albonico,A. Montresor,D. W. T. Crompton and L. Savioli, Intervention for the control of soil- transmitted helminthiasis in the community. Advances in Parasitology, 61, 2006, 311 - 348.

[9]. A. Montresor,D. W. T. Crompton, A. Hall,D. A. P. Bundy and L. Savioli,Guidelines for the evaluation of soil-transmitted helminthiasis and schistosomiasis at community level: A guide for managers of control programmes (Geneva: WHO, 1998).

[10]. C. Andrade,T. D. E. Alava, I. A. Palacio,P. Del Poggio,C. Jamoletti, M. Gulletta and A. Montresor, Prevalence and intensity of soil-transmitted helminthiasis in the city of Portoviejo (Ecuador). Memorias do InstitutoOswaldo Cruz, 96 (8), 2001,1075 - 1079.

[11]. I. A. Awogun, F. E. Okwerekwu,O. A. Oyawoye, and A. B. Bello, Helminthic infections and anaemia among pregnant women attending antenatal clinic in Illorin, Nigeria. Bioscience Research Communique, 7, 1995, 14 - 45

[12]. C. F. Mafiana, M. B. Sodipe and B. I. Koleoso, Soil transmitted helminth parasites of humans in a city in southwestern Nigeria. Helminthlogia, 35 (4), 1998, $203-208$.

[13]. A. K. Taiwoand O. M. Agbolade, Intestinal helminthiasis among school children in Oru, Ogun State, Nigeria. Nigerian Journal of Science, 34, 2000, $283-286$.

[14]. M. G. Ogbe, Edet and M. N. Isichei, Intestinal helminth infection in primary school children in areas of operation of Shell Petroleum Development Company of Nigeria (SPDC), Western Division in Delta State. Nigeria Journal of Parasitology, 23, $2002,3-10$.

[15]. O. A. Adeyeba and A. M. Akinlabi, Intestinal parasitic infections among school children in a rural community, southwest Nigeria. Nigerian Journal of Parasitology, 23, 2002, $11-18$.

[16]. S. E. Etim, P. A. Akpan, S. E. Abeshi and O. E. Effiom, Intestinal helminth infections in children: Implications for helminth control using school based mass chemotherapy.Nigeria Journal of Parasitology, 23, 2002, 53 - 60.

[17]. I. H. Nock, D. Duniyaand M. Galadima,Geohelminth eggs in soil and stools of pupils of some primary schools in Samaru, Zaria, Nigeria. Nigeria Journal of Parasitology, 24, 2003,115 - 122.

[18]. O. M. Ukpaiand C. D. Ugwu, The prevalence of gastrointestinal tract parasites in primary school children Local Government Area of Abia State, Nigeria. Nigeria Journal of Parasitology, 24, 2003,129 - 136.

[19]. O. M. Agbolade, D. O. Akinboyeand A. Awolaja, Intestinal helminthiasis and urinary schistosomiasis in Ijebu North, Ogun State, Nigeria. African Journal of Biotechnology, 3(3), 2004, 206 - 209. [20]. O. A. Egwunyengaand D. P. Ataikiru, Soil-transmitted helminthiasis among school age children in Ethiope East Local
Government area, Delta State, Nigeria. African Journal of Biotechnology, 4(9), 2005, 938 - 941.

[21]. ISLGA,Map of Igbo-Eze South Local Government Area (Ibagwa-Aka, Enugu State, Nigeria: Igbo-Eze South Local Government Secretariat, 2005).

[22]. SUBEB, Statistics of school enrolment(Enugu State, Nigeria: State Universal Basic Education Board, 2005).

[23]. NPC,Final result of 1991 population census of Nigeria (Enugu State, Nigeria: National Population Commission, 1991).

[24]. M. Cheesbrough,District laboratory practice in tropical countries (UK: Cambridge, 1998).

[25]. F. M. A. Ukoli, Prevention and control of parasitic diseases in tropical Africa: the main issues (Ibadan, Nigeria: University Press PLC, 1992).

[26]. S. A. Esrey, J. B. Potash, L. Roberts and C. Shiff, Effects of improved water supplies and sanitation on ascariasis, diarrhoes, dracunculiasis, hookworm infection, schistosomiasis and trachoma. Bulletin of World Health Organization, 69, 1991,609 - 621.

[27]. M. Albonico, D. W. T. Crompton and L. Savioli, Control strategies for human intestinal nematode infections, Advances in Parasitology, 42, 1991, $278-341$.

[28]. C. V. Holland,S. O. Asaolu,D. W. T. Crompton,R. C. Stoddard,R. McDonald and S. E. A. Torimiro, The epidemiology of Ascarislumbricoides and other soil-transmitted helminths in primary school children from Ile-Ife, Nigeria. Parasitology, 99, $1989,275-285$. 